\title{
In Silico Inhibitability of Copper Carbenes and Silylenes against Rhizoctonia solani and Magnaporthe oryzae
}

\author{
Nguyen Thi Thanh Hai, ${ }^{1}$ Thanh Q. Bui ${ }^{1},{ }^{1}$ Tran Thi Ai My, ${ }^{1}$ Huynh Thi Phuong Loan, \\ Tran Thai Hoa $\mathbb{D}^{1},{ }^{1}$ Phan Tu Quy $\mathbb{D},{ }^{2}$ Nguyen Thi Thu Thuy, ${ }^{3}$ Dang Thanh Nhan, ${ }^{4}$ \\ and Nguyen Thi Ai Nhung ${ }^{1}{ }^{1}$ \\ ${ }^{1}$ Department of Chemistry, University of Sciences, Hue University, Hue 530000, Vietnam \\ ${ }^{2}$ Department of Natural Sciences and Technology, Tay Nguyen University, Buon Ma Thuot 630000, Vietnam \\ ${ }^{3}$ Faculty of Agronomy, University of Agriculture and Forestry, Hue University, Hue 530000, Vietnam \\ ${ }^{4}$ Faculty of Forestry Agriculture, Tay Nguyen University, Buon Ma Thuot 630000, Vietnam
}

Correspondence should be addressed to Phan Tu Quy; phantuquy@ttn.edu.vn and Nguyen Thi Ai Nhung; ntanhung@ hueuni.edu.vn

Received 23 January 2021; Accepted 14 December 2021; Published 30 December 2021

Academic Editor: Cristina Femoni

Copyright ( $\odot 2021$ Nguyen Thi Thanh Hai et al. This is an open access article distributed under the Creative Commons Attribution License, which permits unrestricted use, distribution, and reproduction in any medium, provided the original work is properly cited.

Copper lighter tetrylenes are promising for inhibition towards Rhizoctonia solani-based protein PDB-4G9M and Magnaporthe oryzae-based PDB-6JBR in rice. Quantum properties of four hypothetic copper complexes of carbenes and silylenes (Cu-NHC1, $\mathrm{Cu}-\mathrm{NHC2}$, Cu-NHSi1, and $\mathrm{Cu}-\mathrm{NHSi} 2$ ) were examined using the density functional theory. Their inhibitability towards the targeted proteins was evaluated using molecular docking simulation. Quantum analysis predicts the stability of the investigated complexes and thus their practical existability and practicable synthesisability. Their electronic configurations are justified as highly conducive to intermolecular interaction. Regarding ligand-protein as carbenes/silylenes-4G9M inhibitory structures, the stability is estimated in the order [Cu-NHC2]-4G9M (DS $\left.-12.9 \mathrm{kcal} \cdot \mathrm{mol}^{-1}\right)>[\mathrm{Cu}-\mathrm{NHSi1}]-4 \mathrm{G} 9 \mathrm{M}\left(\mathrm{DS}-11.8 \mathrm{kcal} \cdot \mathrm{mol}^{-1}\right)=[\mathrm{Cu}-$ NHSi2]-4G9M (DS $\left.-11.7 \mathrm{kcal} \cdot \mathrm{mol}^{-1}\right)>[\mathrm{Cu}-\mathrm{NHC} 1]-4 \mathrm{G} 9 \mathrm{M}$ (DS $\left.-11.4 \mathrm{kcal} \cdot \mathrm{mol}^{-1}\right)$. In contrast, the corresponding order for the carbenes/silylenes-6JBR systems is $[\mathrm{Cu}-\mathrm{NHSi} 2]-6] B R\left(\mathrm{DS}-13.4 \mathrm{kcal} \cdot \mathrm{mol}^{-1}\right)>[\mathrm{Cu}-\mathrm{NHC} 2]-6 \mathrm{JBR}\left(\mathrm{DS}-13.0 \mathrm{kcal} \cdot \mathrm{mol}^{-1}\right)=[\mathrm{Cu}-$ NHSi1]-6JBR (DS $-12.6 \mathrm{kcal} \cdot \mathrm{mol}^{-1}$ ) $>[\mathrm{Cu}-\mathrm{NHC1}]-6 \mathrm{JBR}$ (DS $-12.3 \mathrm{kcal} \cdot \mathrm{mol}^{-1}$ ). In theory, this study suggests a potentiality of copper lighter tetrylenes and their derivatives against the infection of fungi Rhizoctonia solani and Magnaporthe oryzae, thus encouraging attempts for experimental developments.

\section{Introduction}

Rice (Oryza sativa L.), rich in nutrients, vitamins, and minerals, is well-known to be the most important staple food source for more than seventy percent of the world's population [1]. Given the rapid growth of the global population in the past decades, the demand to secure the production of the plant has been an emergent concern. Nevertheless, rice plants are highly susceptible to many serious diseases caused by microorganisms such as bacteria, viruses, or fungi, resulting in their annual crop yield see dramatic loss [2]. These include rice sheath blight, rooted from the infection of fungi Rhizoctonia solani, and rice blast, caused by fungi Magnaporthe oryzae. According to peasants' experience, yield and severe impacts on rice grain quality are also transparent.

Common signs of sheath blight are the rapid and irregular appearance of light gray to dark brown lesions before they coalesce to cover across larger portions of the sheath and leaf lamina. This disease is known to result in ca. $10-25 \%$ of yield loss [3] and enable a rise up to 50\% under favourable environmental conditions [4]. The cause is demonstrated to be the infection of a soilborne fungal specie, Rhizoctonia solani ( $R$. solani). Also, $R$. solani agglutinin is an important 
protein responsible for the coagulation and aggregation of the fungi to host tissues. Although it is also considered a storage protein and implicated in fungal insecticidal activities, the physiological mechanism remains unclear. Its crystal structure was well-determined [5] and is archived for public reference at the Worldwide Protein Data Bank database under entry PDB-4G9M (DOI: 10.2210/pdb4G9M/ $\mathrm{pdb}$ ). When infection of Magnaporthe oryzae (M. oryzae) is in concern, all parts of the rice plant are vulnerable at any growth stages, and yield loss of $30 \%$ is often reported [6]. The fungus infects the plant by its conidia via appressoria, specialised fungal cells responsible for accumulation of glycerol and dense-layer melanin. In particular, the latter is an essential step for the penetration of $M$. oryzae into host plants. Also, the synthesis of melanin is critically dependent on the activity of an enzymatic superfamily called glycosyltransferase, especially trehalose-6-phosphate synthase [7]. The enzyme accounts for the transfer of glycosyl groups from an activated nucleotide sugar to a nucleophilic glycosyl acceptor. Subsequently, the fungus elaborates the invasion to the underlying plant cells in a very short time. The data of $M$. oryzae enzyme crystal structure can be referenced at Worldwide Protein Data Bank database under entry PDB6JBR (DOI: 10.1042/BCJ20190289). If these proteins are effectively inhibited, inducing conformational changes, their biological activity would be in turn effectively prohibited. Therefore, proteins 4G9M and 6JBR are considered as highly promising drug targets for the treatment of rice sheath blight and rice blast, respectively. Structures of the proteins are presented in Figure 1.

The interest in tetrylene compounds has reemerged following the discovery of highly stable nucleophilic N-heterocyclic carbenes (NHCs) reported by Arduengo et al. $[8,9]$. After the theoretical demonstration, the group successfully synthesised the first NHCs-Ag(I) complexes and isolated free carbene ligands NHC in laboratory experiments [10]. They are well-known for playing important roles as either reactive intermediates or ligands, thereby attracting considerable effort devoted to the systematic understanding of their quantum structures [11]. In nanoengineering, for example, the carbene-based modification was demonstrated as decreasing the electrical conductivity of semiconducting carbon nanotubes without damage to the host graphitic-like $s p 2$ structure [12]. In medicinal application, silver-NHC complexes received intense attention given the promising activity of silver in physiological medium and were, in fact, reported possessing both antimicrobial [13-15] and anticancer [16-18] properties. Recently, a computational research based on molecular docking simulation suggested silver-carbenes hold a significant potentiality for the treatment of SARS-CoV-2 infection [19]. Many other research articles also reported that under certain further appropriate modifications, the complex family is exceptionally compatible for clinical therapy [20, 21]. However, although also well-known for their antimicrobial activity in various deploying forms such as free radicals, nanoparticles, or composite [22-25], the attention for copper tetrylene compounds has still been minor. Moreover, the antifungal efficacy of copper nanoparticles against pathogenic fungi was widely reported in both in vitro $[23,24]$ and in vivo
[26, 27] experiments. Therefore, there are still many untouched potentialities regarding copper tetrylenes and their derivatives in antimicrobial applications in general and fungal inhibition in particular.

Modern medical science is assisted efficiently by the application of in silico techniques, which help reduce cost and time for wet laboratory insignificant trials. In detail, the computational approach is based on various well-developed mathematical models for virtual simulation. As a result, it can predict property-undesirable compounds and effectiveness-promising candidates. The former substances are often eliminated from while the latter compounds are selected for the next analysis or further developed research [28]. In particular, molecular docking simulation has demonstrated its effectiveness in investigating ligand-protein interaction by estimating ligand-target binding energy and static stability of the inhibitory systems [29]. Intermolecular interaction is also included in the output for more in-depth evaluation. The technique, coupled with quantumbased computation (e.g., density functional theory) is considered highly versatile in biochemical research for evaluation of antimicrobial [30], antitumour [31], or antioxidant [32] properties. Recently, Kaddouri et al. applied this strategy to predict bioactivity of mono-, bis-, and tetrakis pyrazole derivatives against a fungal plant pathogen, namely, Fusarium oxysporum f.sp. albedinis, causing Bayoud disease on palms [33].

In this study, the antifungal activity of certain groups of copper lighter tetrylene compounds, that is, carbenes and silylenes, towards Rhizoctonia solani and Magnaporthe oryzae is predicted via computational investigations. The fungus-related proteins are 4G9M and 6JBR, respectively, targeted by potential ligands. Given prerequisites for the safety of physiological applications, the exclusively selected ligands are copper carbenes $(\mathrm{Cu}-\mathrm{NHC1}$ and $\mathrm{Cu}-\mathrm{NHC} 2)$ and copper silylenes (Cu-NHSi1 and $\mathrm{Cu}-\mathrm{NHSi} 2$ ), whose molecular structures are shown in Figure 2. First, density functional theory was implemented on the ligands in an attempt to predict their stability, thus justifying their existability and synthesisability. Afterwards, respective ligand-protein docking simulation was carried out for implication of inhibitability.

\section{Computational Methods}

2.1. Quantum Chemical Calculation. Density functional theory (DFT) was utilised to investigate quantum properties of the hypothetic complexes copper (chloride) carbenes $(\mathrm{Cu}-$ $\mathrm{NHC1}$ and $\mathrm{Cu}-\mathrm{NHC2}$ ) and copper (chloride) silylenes (CuNHSi1 and $\mathrm{Cu}-\mathrm{NHSi} 2$ ). Their molecular geometry was optimised using Gaussian 09 without symmetry constraints [34] at the BP86/def2-SVP level of theory $[35,36]$. For the copper atom, a small-core quasirelativistic effective core potential (ECP) was used. Resolution-of-identity (RI) approximation was applied for each run of optimisation using the appropriate auxiliary basis sets. The criterion of convergence for the SCF energy was set to 10-8 a.u., and the modified integration grid " $\mathrm{m} 4$ " was used. Vibrational frequencies were calculated to confirm that their structures are 


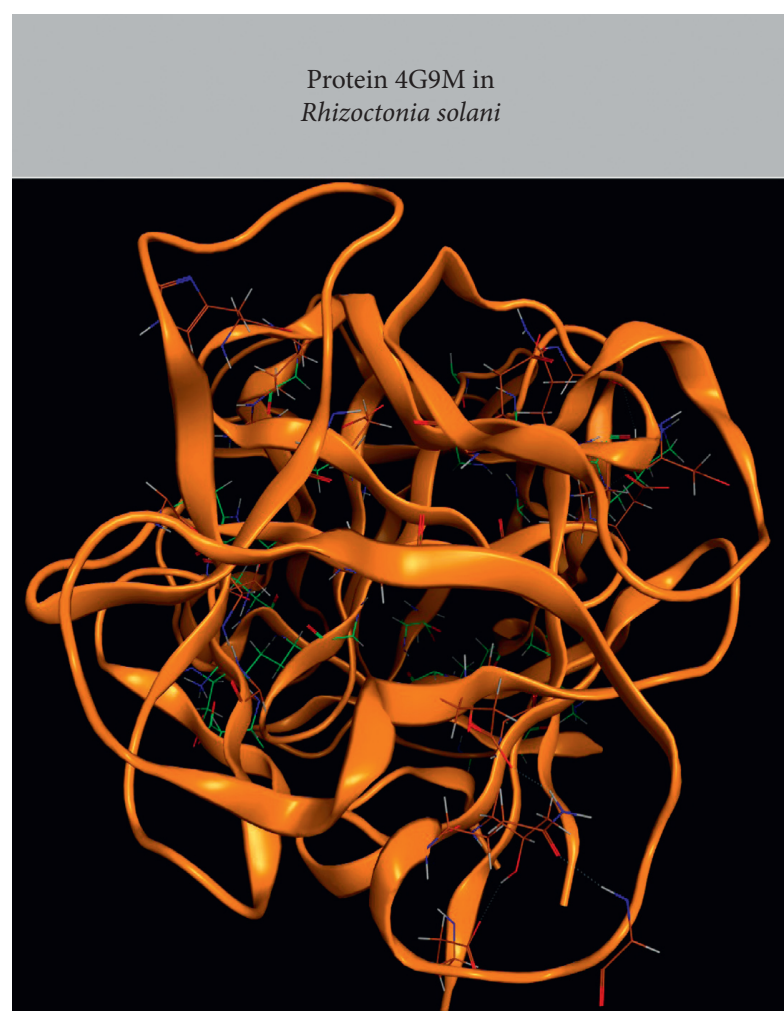

(a)

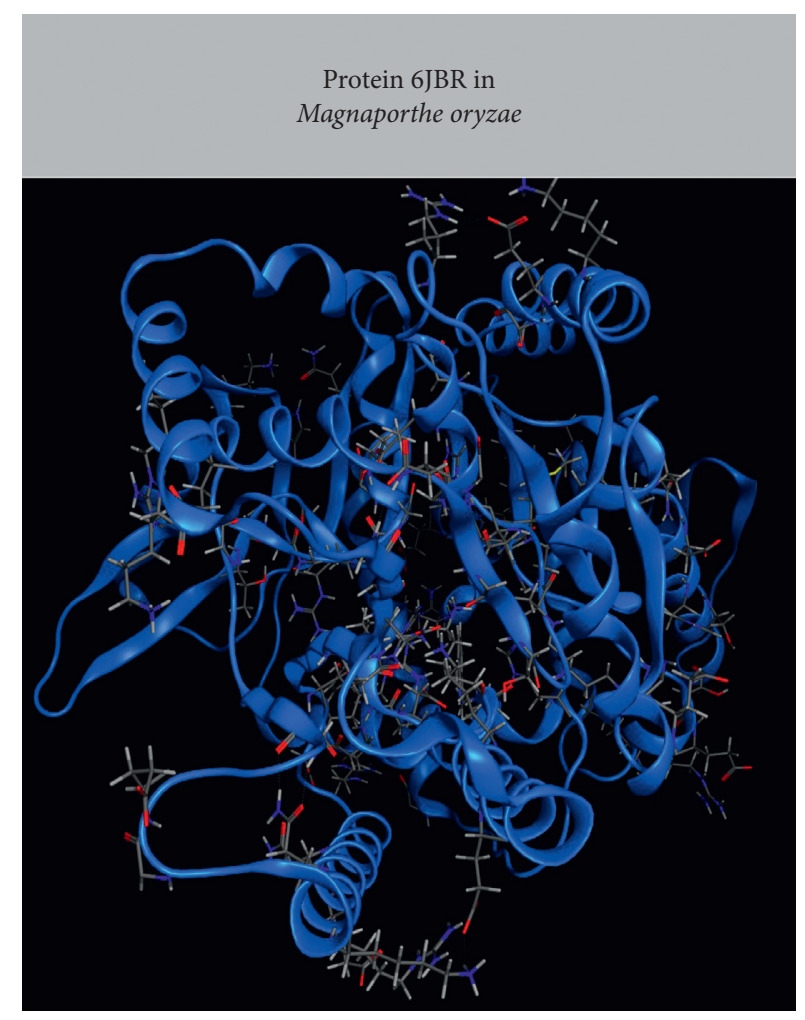

(b)

FIGURE 1: (a) Protein 4G9M in Rhizoctonia solani (DOI:10.2210/pdb4G9M/pdb) and (b) protein 6JBR in Magnaporthe oryzae (DOI:10.2210/ pdb6JBR/pdb), referenced from Worldwide Protein Data Bank.

in a global minimum on the potential energy surface (PES). The harmonic vibrational frequencies were obtained at the same level, BP86/def2-SVP level, for each species to achieve the zero-point vibrational energy (ZPE) corrections. Singlepoint energies at the BP86/def2-SVP-level-optimised geometries were calculated with the frozen-core approximation for nonvalence-shell electrons by a larger basis set def2TZVPP [37]. Resolution-of-identity (RI) approximation was applied for each run of the optimisation. Frontier orbital analysis providing localised molecular orbitals and orbital energy was implemented at the BP86/def2-TZVPP level of theory by NBO 5.1 available in Gaussian 09 [38]. Information of molecular electron density distribution was revealed by bonding analysis. The highest occupied molecular orbital (HOMO) energy, $E_{\mathrm{HOMO}}$, represents intermolecular electron donation tendency. Meanwhile, the electron-accepting ability of a molecule can be inferred from its value $E_{\mathrm{LUMO}}$ (for lowest unoccupied molecular orbital, LUMO). Energy gap $\Delta E=E_{\mathrm{LUMO}}-E_{\mathrm{HOMO}}$ is considered an indicator for intermolecular reactivity as it exhibits the formation of excited-state electrons towards higher energy levels, thus being more available to leave its host molecule. The ionisation potential $(I)$ and electron affinity $(A)$ were calculated using Koopmans' theorem [39, 40], negatively correlating with HOMO and LUMO energy as $I=-E_{\mathrm{HOMO}}$ and $A=-E_{\text {LUMO }}$. They then were used to yield the electronegativity $(\chi)$ of a molecule via equation: $\chi=(I+A) / 2$. Regarding an N-electron system with total electronic energy $(E)$ and external potential $v(r)$, electronegativity $(\chi)$ is defined as the negative value of chemical potential $(\mu)$ $[41,42]$. This can be expressed by the following equation: $\chi=-\mu=-(\partial \mathrm{E} / \partial \mathrm{N})_{\nu(r)}$.

2.2. Molecular Docking Simulation. Molecular docking simulation was implemented on MOE 2015.10 to investigate ligand-protein interactability. The results included intermolecular-complex configurations, docking score (DS) energy, root-mean-square deviation (RMSD), types of interactions, and respective distances between the potential drugs and proteins. In a typical procedure, molecular docking simulation follows four steps [43-45].

\subsubsection{Predocking Preparation}

(i) Selection of proteins in PDB: Crystal structures of protein $4 \mathrm{G} 9 \mathrm{M}$ in $R$. solani and protein $6 \mathrm{JBR}$ in $M$. oryzae were referenced from Worldwide Protein Data Bank under the entries PDB-4G9M (DOI: $10.2210 / \mathrm{pdb} 4 \mathrm{G} 9 \mathrm{M} / \mathrm{pdb}$ ) and PDB-6JBR (DOI: 10.2210/pdb6JBR/pdb), respectively. The investigated ligands were the DFT-optimised lightertetrylene complexes, that is, copper (chloride) carbenes $(\mathrm{Cu}-\mathrm{NHC1}$ and $\mathrm{Cu}-\mathrm{NHC2})$ and copper chloride) silylenes (Cu-NHSil and $\mathrm{Cu}-\mathrm{NHSi} 2$ ).

(ii) Determination of bonding position: The protein action areas were determined based on the ligand positions within a radius of $4.5 \AA$ and the presence of 


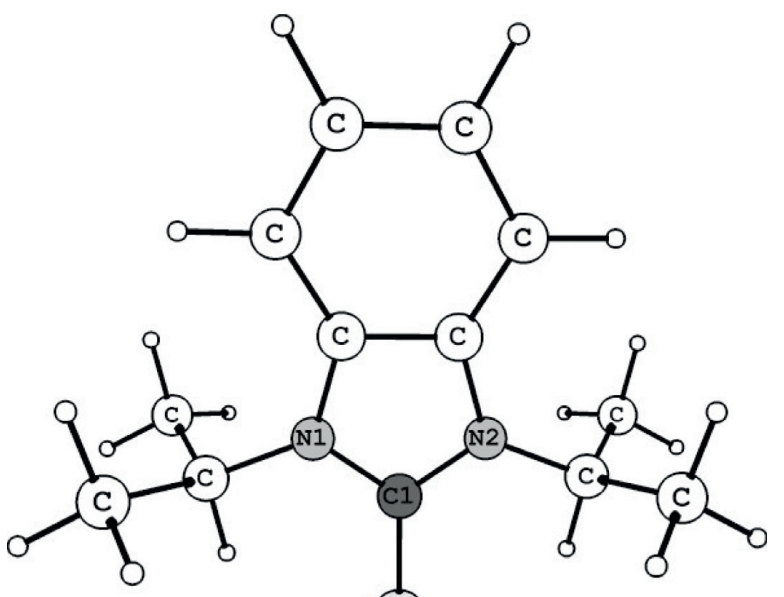

(Cu)<smiles>CC(C)C(C)CC(=[Cr])NCl</smiles>

(c)

(a)

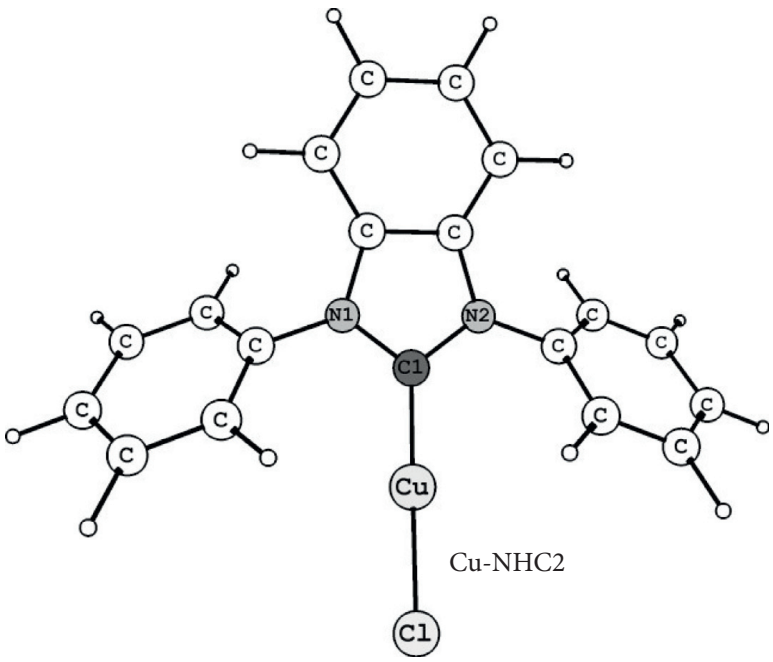

(c)

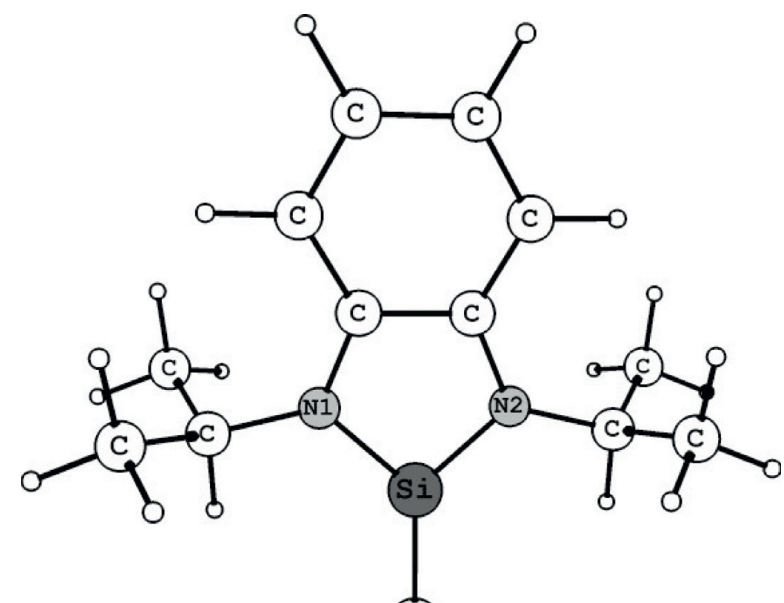

Cu-NHSil

(c1)

(b)

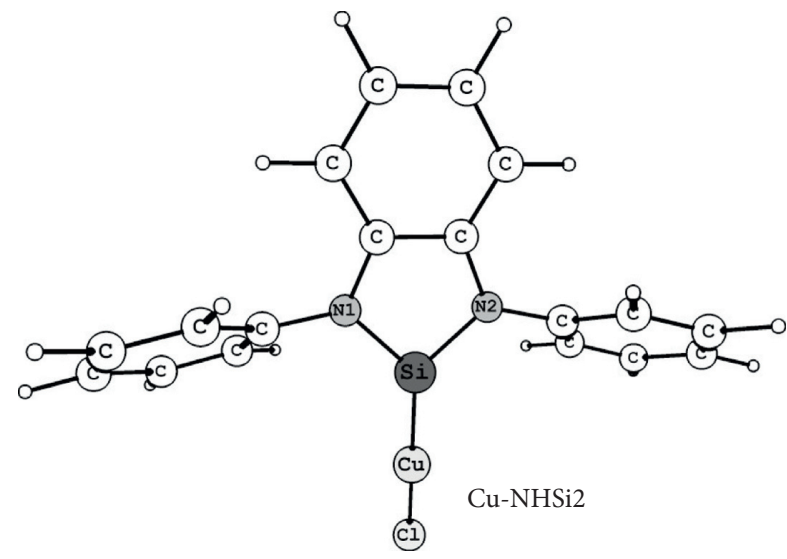

(d)

Figure 2: Structural formula of investigated complexes in this study: copper carbenes, (a) $\mathrm{Cu}-\mathrm{NHC1}$ and (c) $\mathrm{Cu}-\mathrm{NHC} 2$; and copper silylenes, (b) Cu-NHSi1 and (d) Cu-NHSi2.

important amino acids. Water molecules were removed, and the structures of amino acids were checked before reestablishing the enzyme action areas.

(iii) Lowest energy state: The 3D molecular structures of the compounds were then optimised to correct the mismatch values of bond lengths, bond angles, bending angles, and unusual nonbonding interactions due to the atoms in different parts of the compounds occupying the same space.

(iv) Plotting chemical structures of the compounds: The protein 3D-protonation structures were prepared by Quickprep tool following configuration: Tether-Receptor with the strength of 5000; Refine of $0.0001 \mathrm{kcal} \cdot \mathrm{mol}^{-1} \cdot \AA^{-1}$, while their active zones were determined based on the ligand position within a radius of $4.5 \AA$ and the presence of important amino acids. The achieved structures were saved in * pdb format. Independently, the ligand structures, that is, $\mathrm{Cu}-\mathrm{NHC1}$, Cu-NHC2, Cu-NHSi1, and Cu-NHSi2, were optimised based up the configuration: Conj Grad for minima energy; termination for energy change $=0.0001 \mathrm{kcal} \cdot \mathrm{mol}^{-1} ; \max$ interactions $=1000$; modify charge: Gasteiger-Huckel. The program is automatically iterated five times to find the various configurations needed, and then the minimized energy was observed again to determine steric energy. In this way, the structural parameters of compounds with different energy were found, which were more durable than the original structures.

2.2.2. Docking Investigation. After preparation for input, intermolecular interaction simulation was performed on MOE 2015.10 system under the configuration: poses retaining for intermolecular interaction probing $=10$; 
maximum solutions per iteration $=1000$; and maximum solutions per fragmentation $=200$. The simulated ligandprotein inhibitory structures were saved in format $*$.sdf.

2.2.3. Redocking. Redocking of protein-compound cocrystal structures: the redocking of protein-ligand complex cocrystal structures aims to assess the suitability of docking parameters. The process was carried out with three structures of compounds as follows:

(1) Separation of compounds from homogenized complexes in proteins.

(2) Separation of compounds from homogeneous complexes and repreparation.

(3) Preparation of the new compounds (structure drawing, structural optimisation parameters on minima energy).

Root-mean-square deviation (RMSD) values reflect the deviation of compounds structures after docking compared to available structures in the crystal structure and comparing the interactions of compounds in the crystal structure after docking. The docking results are considered reliable when the RMSD value is $<1.5 \AA$ and the interactions between compounds and the initial enzyme are not significantly different.

2.2.4. Postdocking Analysis. Docking score (DS) energy indicates Gibbs free energy of the respective ligand-protein inhibitory system, thus considered as the primary indicator of the duo-system inhibitability. Intermolecular interactions formed between the ligands and in-pose amino acids of the proteins include hydrophilic binding, for example, electrontransferring (H-acceptor/donor), cation-arene $(\mathrm{H}-\pi)$, arene-arene $(\pi-\pi)$, and ionic and hydrophobic interaction, aka. van der Waals forces. The simulation results in-bonding amino acids, bonding lengths, and their Gibbs free energy in regard to these interactions. A root-mean-square deviation (RMSD) value predicts the static conformation of an inhibitory complex as it represents the average between neighbouring atoms. Therefore, a smaller value means a more tightly bound conformation is formed. In addition, inpose arrangement of the ligands was rendered on $2 \mathrm{D}$ and $3 \mathrm{D}$ planes.

\section{Results and Discussion}

3.1. Quantum Properties. The geometrically optimised structure of the studied complexes and their NBO analysis are shown in Figure 3 and Table 1, respectively. The results reveal that the tetrylene ligands-fragments $\mathrm{CuCl}$ bonding are in a head-on configuration, whose bending angle is $180.0^{\circ}$. First, it is noticeable that the main bonds, that is, $\mathrm{N}-\mathrm{C} 1$ and $\mathrm{C} 1-\mathrm{Cu}$, in copper carbenes (ca. 1.37 and $1.87 \AA$, respectively) are significantly shorter than those of silylenes (ca. 1.75 and $2.2 \AA$, respectively). Also, the central carbon (C1) of the former compounds are considered in $s p^{3}$-hybridisation as their bonding is oriented at angles of $105.5-106.3^{\circ}$, approximate to characteristic tetrahedral geometry $\left(109.5^{\circ}\right)$. In contrast, the corresponding figures for their silylene counterparts are $90.1^{\circ}$ and $91.2^{\circ}$, characterised for the unhybridised configuration. These suggest an elevated stability regarding the overall molecular structure of copper carbenes in comparison to the silylene family. Nevertheless, the Wiberg bond indices (WBI) obtained from the NBO analysis indicate that the electronic density between the main bonds, that is, $\mathrm{C}-\mathrm{Cu}, \mathrm{C}-\mathrm{N}$, and $\mathrm{Cu}-\mathrm{Cl}$, in copper silylenes is slightly higher than the one calculated for the copper carbenes. This means that the localised stability at these bonds sees an inverse pattern. Also, the natural partial charge of fragments $\mathrm{CuCl}$ was calculated negative, from -0.36 to -0.23 , for all molecules, which are significantly contributed by their chlorine charges of ca. -0.6 . Overall, the results predict the existability of the copper tetrylenes, $\mathrm{Cu}$ $\mathrm{NHC1}$, Cu-NHC2, Cu-NHSi1, and Cu-NHSi2, given their stableness.

The molecular orbitals whose probability density morphology represents $\sigma$ - and $\pi$-type of bonding are depicted in Figure 4. In general, the former is found at either HOMO-5 (Cu-NHC1 and Cu-NHSi1) or HOMO-9 (Cu-NHC2 and $\mathrm{Cu}-\mathrm{NHSi} 2$ ), while the latter is determined at HOMO-3. They are all observed occupying spatially large volumes in and are distributed rather evenly over the molecular planes, conducive to the respective bonding stability. In detail, the densities are distributed dominantly along the central pentaheterocyclic groups and $\mathrm{X}-\mathrm{Cu}-\mathrm{Cl}(\mathrm{X}=C, \mathrm{Si})$, except for $\pi$ bonds of the two copper carbenes whose electronic densities spread across almost the molecules. Furthermore, the orbitals register the values of energy level from -8.417 to $-9.736 \mathrm{eV}$, considered stable (commonly agreed under $-5 \mathrm{eV})$. In detail, the $\sigma$-type bonds of the silylenes are expected to be more stable than the carbene counterparts given their lower energy levels while the corresponding pattern for the $\pi$-type is inverse. Therefore, the preanalysis on geometrical stability is highly justified.

The HOMO-LUMO leaps and in-detail results regarding band-gap analysis of the studied molecules are shown in Figure 5 and summarised in Table 2, respectively. In particular, the values of their band-gap energy vary between 6.003 and $7.075 \mathrm{eV}$, lying on the transition of an insulator $(>9 \mathrm{eV})$ and a semiconductor $(<3.2 \mathrm{eV})$ [46]. This would be conducive to the intermolecular binding capability towards protein structures as the polypeptide molecules were proposed and well-proven performing electrical conductivity $[47,48]$. Later, the superexchange theory (or electron tunneling) and the electron hopping model were accepted as the more accurate view for this phenomenon [49]. Besides, the HOMO and LUMO electronic densities are observed as evenly distributed and largely space-occupied over their corresponding molecular planes, thus justifying the proposed inhibition to be flexible via various approaching manners. In addition, the significance of their electronegativity suggests electron-attracting tendencies, in turn upholding their external electron-transfer. Altogether, the ligand-protein peripheral interactability, thus inhibitability, derived by $\mathrm{Cu}-\mathrm{NHC1}, \mathrm{Cu}-\mathrm{NHC} 2, \mathrm{Cu}-\mathrm{NHSi1}$, and $\mathrm{Cu}-$ NHSi2 are highly promising. 


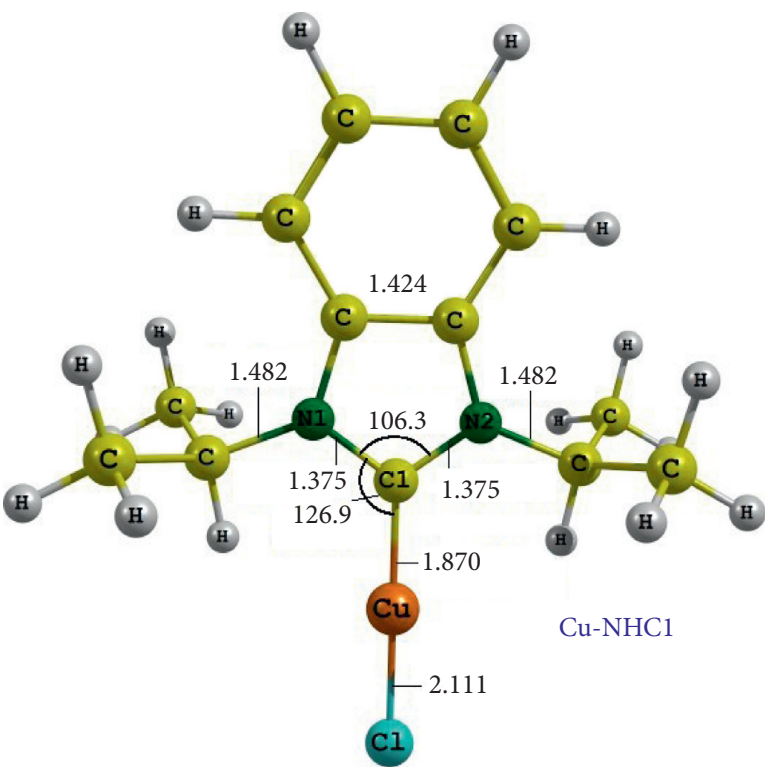

(a)

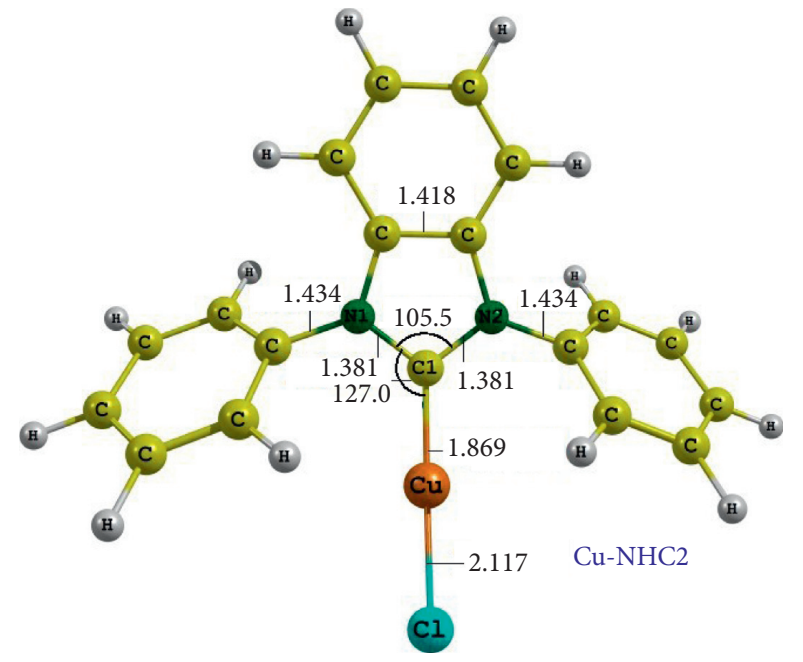

(c)

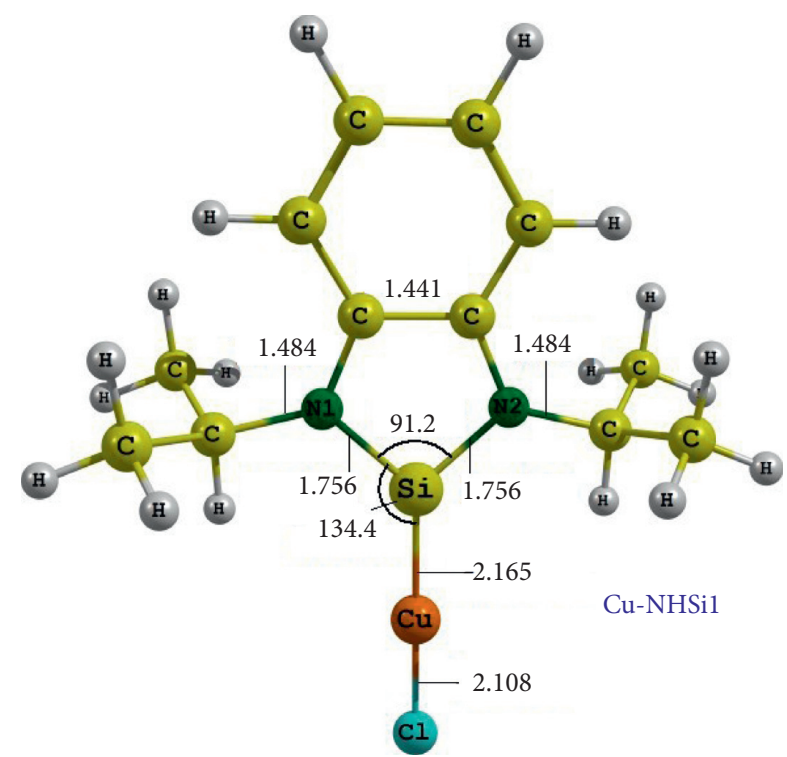

(b)

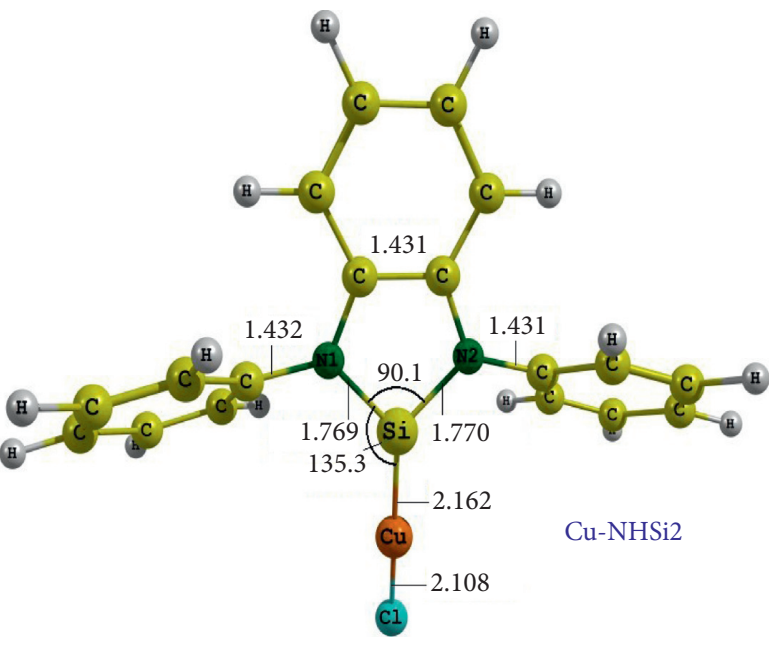

(d)

FIgURE 3: Optimised structures of copper chloride-carbenes (Cu-NHC1 and $\mathrm{Cu}-\mathrm{NHC} 2)$ and copper chloride-silylenes (Cu-NHSil and $\mathrm{Cu}-$ NHSi2) using BP86/def2-SVP computations.

3.2. Molecular Docking Simulation. According to the methodology of molecular docking simulation applied for ligand-protein inhibitory systems, an associated docking score (DS) is considered as the main indicator for inhibitory effects, whose value lower than $-3.2 \mathrm{kcal} \cdot \mathrm{mol}^{-1}$ indicates good binding capacity $[44,45]$. In principle, the figure is yielded by the free-energy sum of all individual intermolecular interactions, whose affinity stems from hydrophilic bonding, that is, various hydrogen-bond types, and hydrophobic binding, that is, van der Walls forces. Besides, a root-mean-square deviation (RMSD) value over $3 \AA$ reveals that the inhibition expects failure. Meanwhile, the threshold of docking success is widely acceptable if $\leq 2 \AA$ [50]. Also, visual illustration for inhibitory morphology and interaction description is provided with descriptive symbols listed in Figure 6.
The quaternary structure of the targeted proteins (Rhizoctonia solani-based 4G9M and Magnaporthe oryzae-based 6JBR) and their approachable sites by the studied tetrylenes are virtually represented in Figure 7. The corresponding in-pose amino acid residues are listed in Table 3. The results of prescreening on the inhibitability of each copper ligand towards these potential sites are summarised in Table 4 . There are four sites enabling the copper complexes to enter, assigned as site 1 (yellow), site 2 (green), site 3 (cyan), and site 4 (blue). Regarding protein 6JBR, site 1 comprises 63 different amino acids, a dominant number in comparison to others, implying its highest potential for intermolecular interactions formed these residues. In fact, prescreening results also indicate that it is the most active site for the copper tetrylene compounds given by both the lowest DS values (varying from -12.3 to $-13.4 \mathrm{kcal} \cdot \mathrm{mol}^{-1}$ ) and the number of 
TABLE 1: Results of NBO analysis on copper carbenes and copper silylenes: $\mathrm{Cu}-\mathrm{NHC1}, \mathrm{Cu}-\mathrm{NHC} 2, \mathrm{Cu}-\mathrm{NHSi1}$, and Cu-NHSi2 at the level of theory BP86/def2-TZVPP//BP86/def2-SVP.

\begin{tabular}{|c|c|c|c|c|c|}
\hline Molecule & Bond & WBI & Atom & NPA & $\mathrm{q}_{\mathrm{CuCl}}$ \\
\hline \multirow{4}{*}{$\mathrm{Cu}-\mathrm{NHCl}$} & $\mathrm{C}-\mathrm{Cu}$ & 0.23 & $\mathrm{Cu}$ & 0.39 & -0.24 \\
\hline & $\mathrm{C}-\mathrm{N} 1$ & 0.36 & C & 0.20 & \\
\hline & $\mathrm{C}-\mathrm{N} 2$ & 0.36 & $\mathrm{~N} 1 ; \mathrm{N} 2$ & 0.35 & \\
\hline & $\mathrm{Cu}-\mathrm{Cl}$ & 0.42 & $\mathrm{Cl}$ & -0.63 & \\
\hline \multirow{4}{*}{ Cu-NHSi1 } & $\mathrm{Si}-\mathrm{Cu}$ & 0.33 & $\mathrm{Cu}$ & 0.26 & -0.36 \\
\hline & Si-N1 & 0.47 & $\mathrm{Si}$ & 1.25 & \\
\hline & $\mathrm{Si}-\mathrm{N} 2$ & 0.47 & N1; N2 & -0.78 & \\
\hline & $\mathrm{Cu}-\mathrm{Cl}$ & 0.41 & $\mathrm{Cl}$ & -0.62 & \\
\hline \multirow{4}{*}{$\mathrm{Cu}-\mathrm{NHC} 2$} & $\mathrm{C}-\mathrm{Cu}$ & 0.24 & $\mathrm{Cu}$ & 0.39 & -0.23 \\
\hline & $\mathrm{C}-\mathrm{N} 1$ & 0.37 & C & 0.21 & \\
\hline & $\mathrm{C}-\mathrm{N} 2$ & 0.37 & $\mathrm{~N} 1 ; \mathrm{N} 2$ & -0.36 & \\
\hline & $\mathrm{Cu}-\mathrm{Cl}$ & 0.41 & $\mathrm{Cl}$ & -0.62 & \\
\hline \multirow{4}{*}{$\mathrm{Cu}-\mathrm{NHSi} 2$} & $\mathrm{Si}-\mathrm{Cu}$ & 0.33 & $\mathrm{Cu}$ & 0.28 & -0.34 \\
\hline & Si-N1 & 0.48 & $\mathrm{Si}$ & 1.26 & \\
\hline & $\mathrm{Si}-\mathrm{N} 2$ & 0.48 & $\mathrm{~N} 1 ; \mathrm{N} 2$ & -0.77 & \\
\hline & $\mathrm{Cu}-\mathrm{Cl}$ & 0.41 & $\mathrm{Cl}$ & -0.62 & \\
\hline
\end{tabular}

WBI: Wiberg bond indices; NPA: natural partial charge (e).

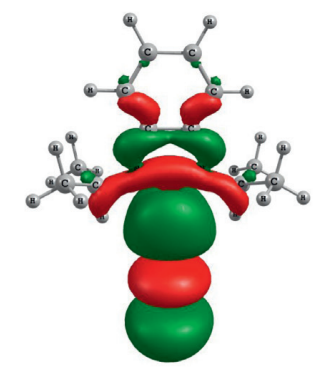

$\mathrm{Cu}-\mathrm{NHC1}$ HOMO-5 $(\sigma)$ $-9.334 \mathrm{eV}$
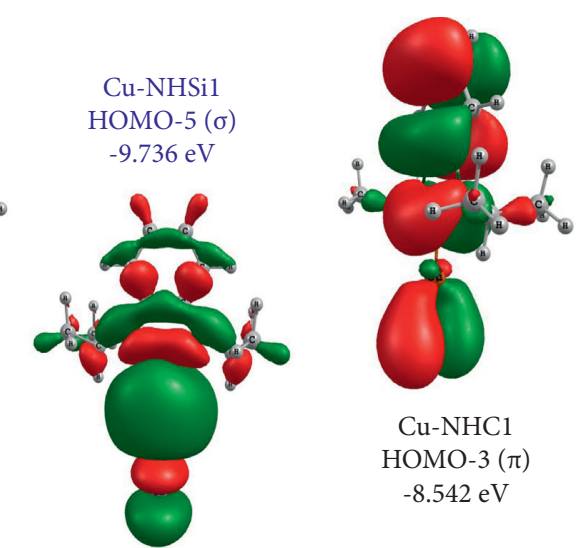

$\mathrm{Cu}-\mathrm{NHC1}$

$\mathrm{HOMO}-3(\pi)$ $-8.542 \mathrm{eV}$
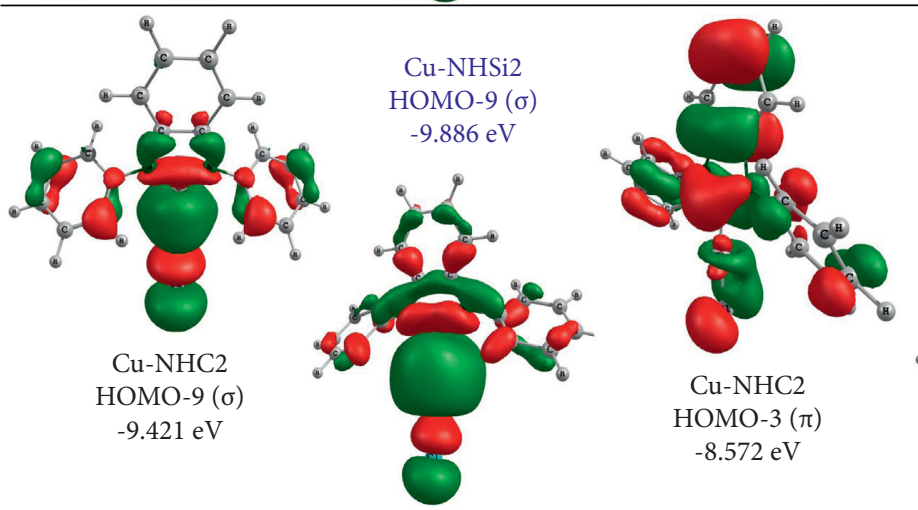

$\mathrm{Cu}-\mathrm{NHC2}$

HOMO-3 $(\pi)$ $-8.572 \mathrm{eV}$
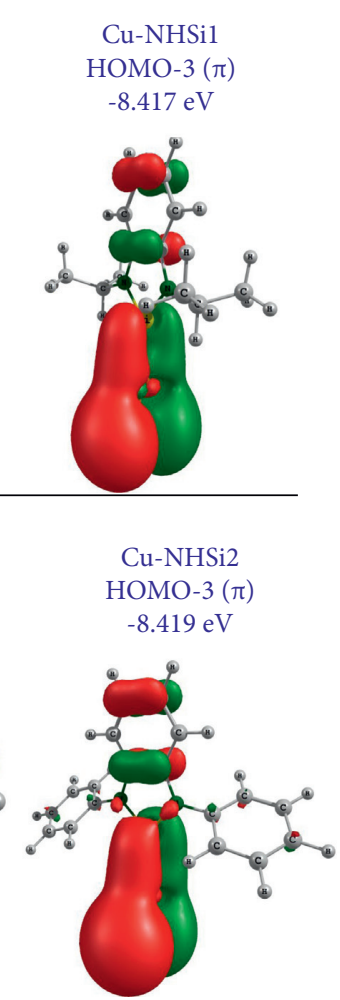

Figure 4: Molecular orbitals and orbital energy levels of $\sigma$ - and $\pi$-types MOs of copper tetrylenes, Cu-NHC1, Cu-NHSi1, Cu-NHC2, $\mathrm{Cu}-\mathrm{NHSi} 2$, at the level of theory BP86/TZVPP.

interactions created (at least 4). Regarding protein 4G9M, the carbenes are most activated for the inhibition when in site 1 , while the corresponding site for the silylenes is 4 . Their DS values register between -11.4 and $-12.9 \mathrm{kcal} \cdot \mathrm{mol}^{-1}$ while there are 2-5 interactions formed for each inhibitory system. Therefore, they were selected for a more in-depth investigation on molecular docking simulation and the obtained data are presented in Table 5.
DS value for [Cu-NHC2]-4G9M registers $-12.9 \mathrm{kcal} \cdot \mathrm{mol}^{-1}$, the highest magnitude calculated among all ligand-4G9M inhibitory systems. This means the complex is at the lowest free-energy level, thereby most stable. Its significance of inhibitability towards the protein is justified by comparison to the corresponding value derived from a commercial drug (validamycin) for sheath blight of rice, $-12.3 \mathrm{kcal} \cdot \mathrm{mol}^{-1}$, on a resembling simulation [51]. In detail, 


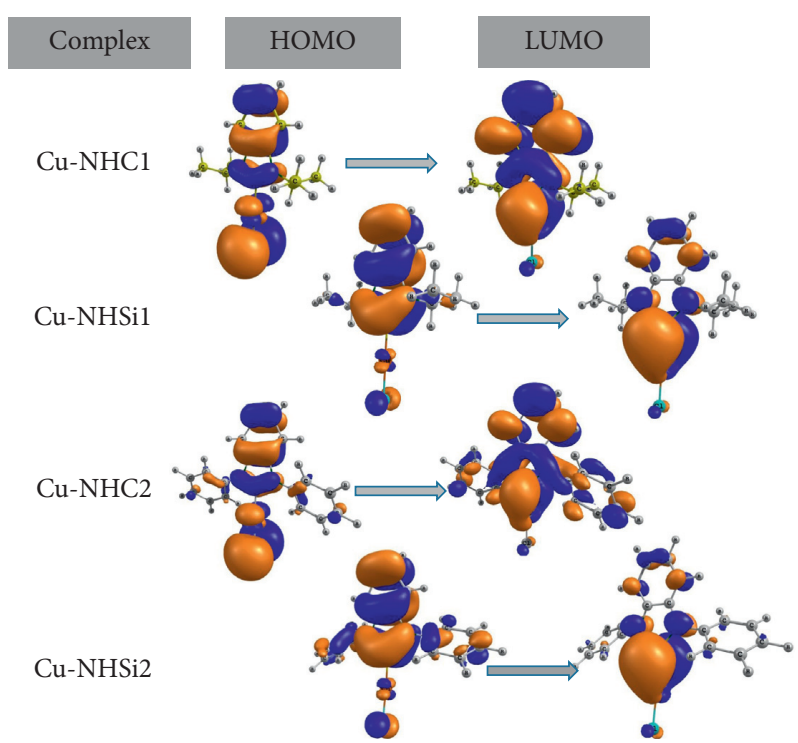

Figure 5: HOMO and LUMO of copper tetrylenes, Cu-NHC1, Cu-NHSi1, Cu-NHC2, Cu-NHSi2, calculated by DFT at the level of theory BP86/def2-TZVPP.

TABle 2: Quantum chemical parameters of copper carbenes and copper silylenes, $\mathrm{Cu}-\mathrm{NHC1}, \mathrm{Cu}-\mathrm{NHC} 2, \mathrm{Cu}-\mathrm{NHSi1}$, and Cu-NHSi2, calculated by NBO analysis at the level of theory BP86/def2-TZVPP.

\begin{tabular}{|c|c|c|c|c|}
\hline Parameter & $\mathrm{Cu}-\mathrm{NHC1}$ & $\mathrm{Cu}-\mathrm{NHSi} 1$ & $\mathrm{Cu}-\mathrm{NHC} 2$ & $\mathrm{Cu}-\mathrm{NHSi} 2$ \\
\hline$E_{\text {Hомо }}(\mathrm{eV})$ & -7.815 & -7.532 & -7.821 & -7.606 \\
\hline$E_{\text {LUMO }}(\mathrm{eV})$ & -0.740 & -1.426 & -0.893 & -1.603 \\
\hline$\Delta E_{G A P}=E_{\mathrm{LUMO}}-E_{\mathrm{HOMO}}$ & 7.075 & 6.106 & 6.928 & 6.003 \\
\hline$I=-E_{\mathrm{HOMO}}$ & 7.815 & 7.532 & 7.821 & 7.606 \\
\hline$A=-E_{\mathrm{LUMO}}$ & 0.740 & 1.426 & 0.893 & 1.603 \\
\hline$\chi=(I+A) / 2$ & 4.278 & 4.479 & 4.357 & 4.605 \\
\hline$\mu=-\chi=-(\partial \mathrm{E} / \partial \mathrm{N})_{\nu(r)}$ & -4.278 & -4.479 & -4.357 & -4.605 \\
\hline
\end{tabular}

$E_{\mathrm{HOMO}}: \mathrm{HOMO}$ energy $(\mathrm{eV}) ; E_{L U M O}: \mathrm{LUMO}$ energy $(\mathrm{eV}) ; \Delta E_{\mathrm{GAP}}$ : gap energy $(\mathrm{eV}) ; \mathrm{I}$ : ionisation potential; $A$ : electron affinity; $\chi$ : electronegativity; $\mu$ : chemical potential.

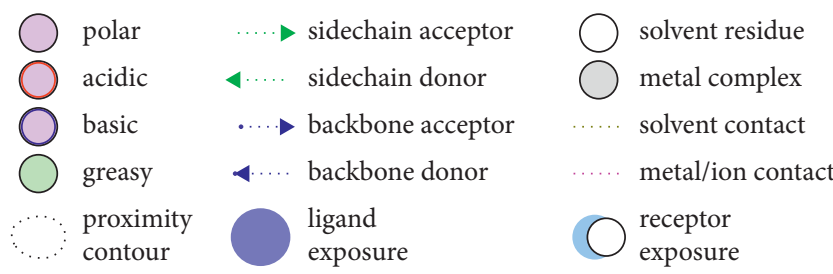

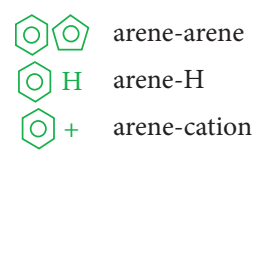

FIGURE 6: Descriptive denotation for in-pose interactions projected by MOE2015.10 molecular docking simulation.

$\mathrm{Cu}-\mathrm{NHC2}$ exhibits hydrophilic affinity with various types of $4 \mathrm{G} 9 \mathrm{M}$ in-pose amino acids, that is, glu102, leu90, gly55, and asn56, creating a variety of bonding types (H-donor, ionic, and $\pi-\mathrm{H})$ and summing a total hydrophilic free energy of $-5.1 \mathrm{kcal} \cdot \mathrm{mol}^{-1}$. These interactions are formed within the distance of ca. $5 \AA$. Besides, hydrophobic bonding between the ligand and its targeted protein is constituted by 12 van der Waals interactions. Although the inhibitory complex [Cu-NHC2]-4G9M is unexpected to be a biological rigid body as the corresponding RMSD is $1.73 \AA$; the figure is still considered tolerable for docking success $(<2 \AA)$ [50]. Meanwhile, there are no significant differentials recorded given either DS values or the number of hydrogen-bond interactions between other ligand-protein docked systems:
[Cu-NHC1]-4G9M, [Cu-NHSi1]-4G9M, and [Cu-NHSi2]4G9M. They also register the RMSD values representing inhibitory stability. In brief, the order $\mathrm{Cu}-\mathrm{NHC} 2>\mathrm{Cu}-$ $\mathrm{NHSi} 1=\mathrm{Cu}-\mathrm{NHSi} 2>\mathrm{Cu}-\mathrm{NHC} 1$ indicates the predicted inhibitory effectiveness of the tetrylene ligands towards protein 4G9M.

Overall, hydrophilic interactions formed in ligand-6JBR systems are more than those in the 4G9M-based counterparts. This signifies the elevated stability of the former. In particular, the highest value obtained regarding virtual investigations on protein $6 \mathrm{JBR}$ is $-13.4 \mathrm{kcal} \cdot \mathrm{mol}^{-1}$, accounting for the stability of [Cu-NHSi2]-6JBR. This is marginally followed by the corresponding figure for [Cu-NHC2]-6JBR, $-13.0 \mathrm{kcal} \cdot \mathrm{mol}^{-1}$. Also, the average distance between their 


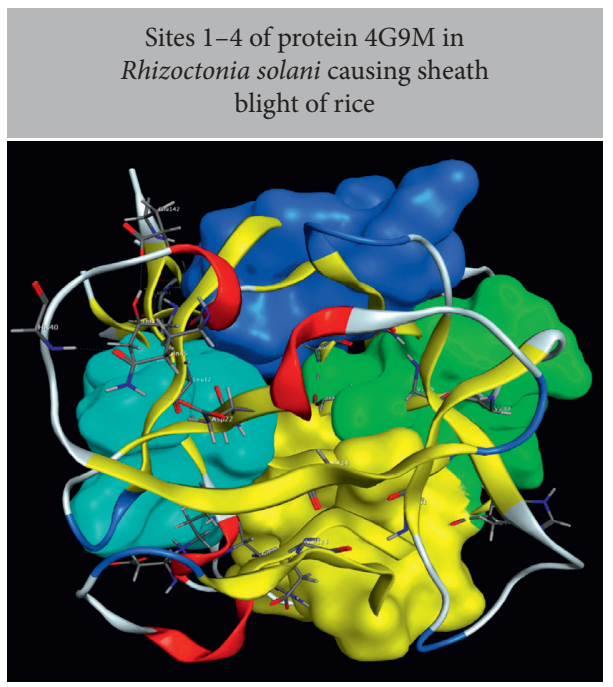

(a)

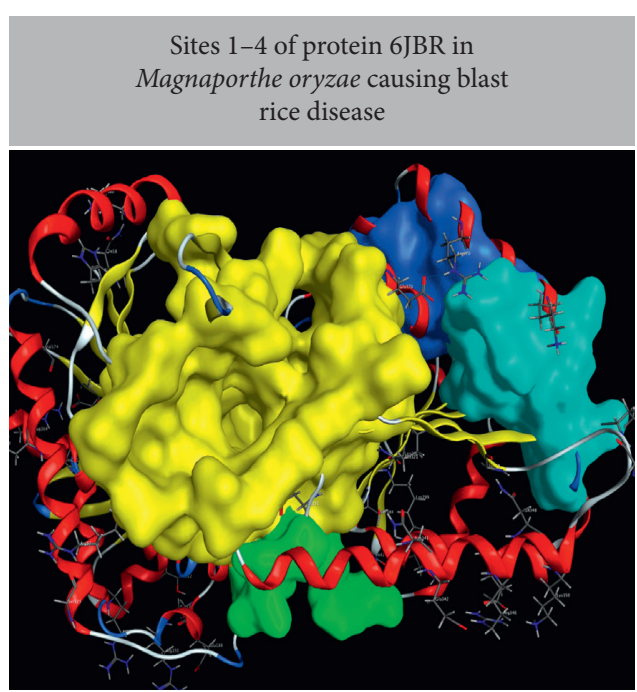

(b)

FIGURE 7: Quaternary structures of proteins (a) 4G9M and (b) 6JBR with their approachable sites by the investigated copper carbenes and copper silylenes: site 1 (yellow), site 2 (green), site 3 (cyan), and site 4 (blue).

TABLE 3: In site amino acid residues of proteins 4G9M and 6JBR.

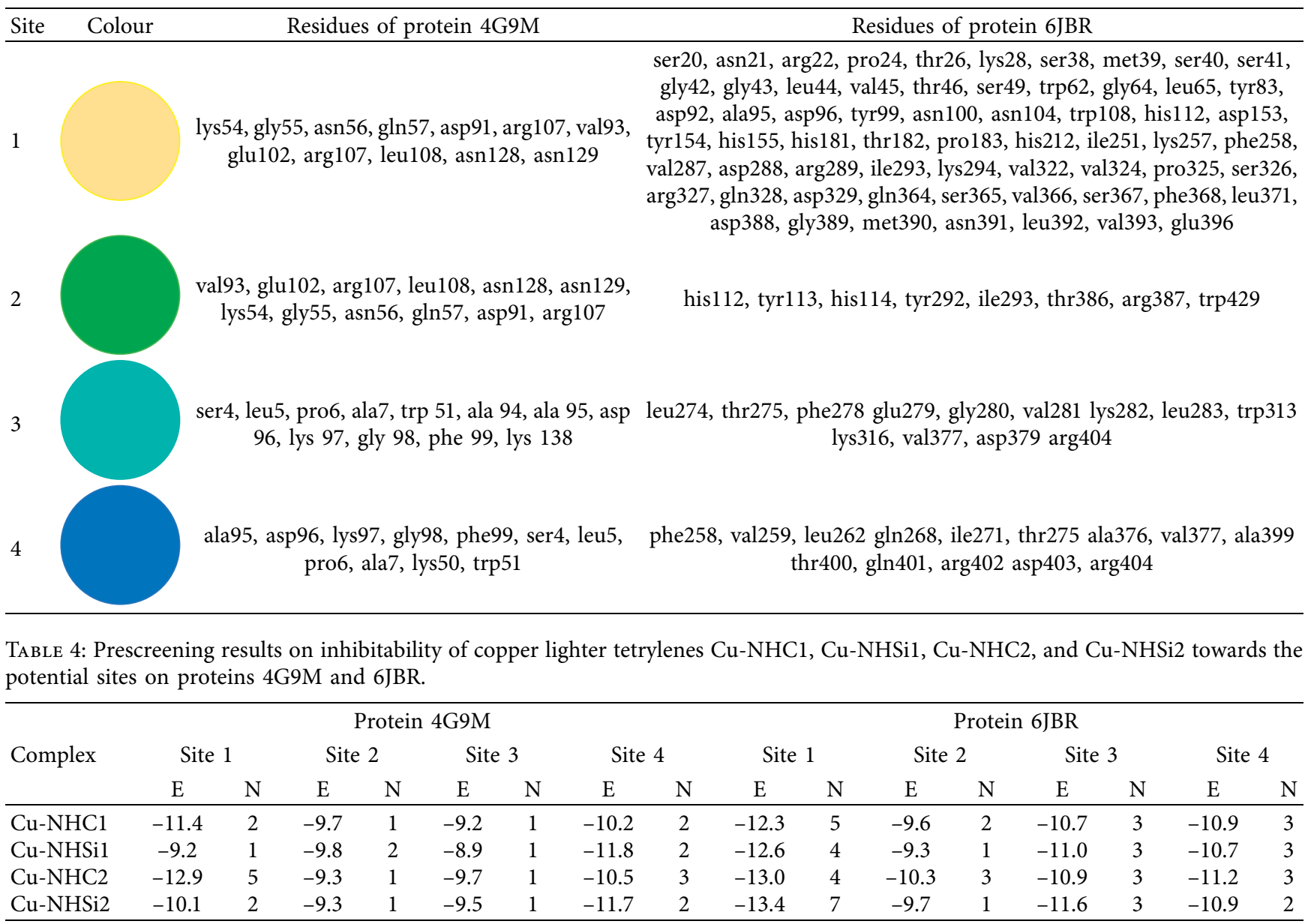

(E): DS value $\left(\mathrm{kcal} \cdot \mathrm{mol}^{-1}\right) ;(\mathrm{N})$ : number of interactions.

in-pose atoms is almost resembled given by their RSMD values, which are 1.14 and $1.16 \AA$, respectively. Otherwise, $\mathrm{Cu}-\mathrm{NHCSi1}$ and $\mathrm{Cu}-\mathrm{NHC1}$ are predicted as less effective inhibitors towards protein 6JBR given their lower DS values, which are -12.6 and $-12.34 \mathrm{kcal} \cdot \mathrm{mol}^{-1}$, respectively. However, the findings from all potential inhibitors are still 
TABLE 5: Molecular docking simulation results for ligand-protein inhibitory structures: [Cu-NHC1]-4G9M, [Cu-NHSi1]-4G9M, [CuNHC2]-4G9M, [Cu-NHSi2]-4G9M, [Cu-NHC1]-6JBR, [Cu-NHSi1]-6JBR, [Cu-NHC2]-6JBR, and [Cu-NHSi2]-6JBR.

\begin{tabular}{|c|c|c|c|c|c|c|c|c|}
\hline \multicolumn{3}{|c|}{ Ligand-protein complex } & \multicolumn{5}{|c|}{ Hydrogen bond } & \multirow{2}{*}{ Van der Waals interaction } \\
\hline Name & DS & RMSD & $\mathrm{L}$ & $P$ & $\mathrm{~T}$ & $\mathrm{D}$ & $\mathrm{E}$ & \\
\hline \multirow{2}{*}{ [Cu-NHC1]-4G9M } & \multirow{2}{*}{-11.4} & \multirow{2}{*}{1.16} & $\mathrm{Cu}$ & $\begin{array}{c}\mathrm{O}, \\
\text { glu102 }\end{array}$ & Metal & 2.38 & -1.7 & \multirow{2}{*}{$\begin{array}{l}\arg (\mathrm{b}) 107, \arg (\mathrm{a}) 107, \operatorname{gln}(\mathrm{a}) 57, \operatorname{asn}(\mathrm{b}) 130, \operatorname{asn}(\mathrm{a}) 56, \operatorname{gly}(\mathrm{a}) \\
\text { 55, val(b)93, glu(a)102, leu(b)108, } \operatorname{asn}(\mathrm{b}) 129, \operatorname{asp}(\mathrm{a}) 91\end{array}$} \\
\hline & & & $\mathrm{N}$ & $\begin{array}{l}\mathrm{O} \\
\text { glu } 102\end{array}$ & Ionic & 3.92 & -0.7 & \\
\hline \multirow[t]{2}{*}{ [Cu-NHSi1]-4G9M } & \multirow{2}{*}{-11.8} & \multirow{2}{*}{1.37} & $\mathrm{~N}$ & $\begin{array}{c}\mathrm{O} \\
\text { asp96 }\end{array}$ & Ionic & 3.24 & -3.1 & \multirow{2}{*}{ lys(a)97, ala(b)7, trp(b)51, gly(b)53, thr(b)52 } \\
\hline & & & 6-Ring & $\begin{array}{c}\mathrm{C}, \\
\text { asp96 }\end{array}$ & $\pi-\mathrm{H}$ & 3.64 & -0.7 & \\
\hline \multirow{5}{*}{ [Cu-NHC2]-4G9M } & \multirow{5}{*}{-12.9} & \multirow{5}{*}{1.73} & $\mathrm{C}$ & $\begin{array}{c}\mathrm{O}, \\
\text { glu102 }\end{array}$ & H-donor & 3.04 & -0.9 & \multirow{5}{*}{$\begin{array}{l}\text { lys(a)54, asn(b)129, gln(a)57, leu(b)108, pro(a)89, val(a)58, } \\
\text { asp(a)91, ala(a)104, } \arg (\text { b) 107, } \arg (a) 107, \operatorname{val}(\mathrm{b}) 93, \operatorname{lys}(\mathrm{a}) 54\end{array}$} \\
\hline & & & $\mathrm{Cl}$ & O, leu90 & H-donor & 2.28 & -0.3 & \\
\hline & & & $\mathrm{N}$ & $\begin{array}{c}\mathrm{O} \\
\text { glu102 }\end{array}$ & Ionic & 3.39 & -2.4 & \\
\hline & & & 5-Ring & C, gly55 & $\pi-\mathrm{H}$ & 4.72 & -0.7 & \\
\hline & & & 6-Ring & $\begin{array}{c}\mathrm{N} \text {, asn } \\
56\end{array}$ & $\pi-\mathrm{H}$ & 4.61 & -0.8 & \\
\hline \multirow{2}{*}{ [Cu-NHSi2]-4G9M } & \multirow{2}{*}{-11.7} & \multirow{2}{*}{1.40} & $\mathrm{~N}$ & $\begin{array}{c}\mathrm{O} \\
\text { asp96 }\end{array}$ & Ionic & 3.87 & -0.8 & \multirow{2}{*}{ ala(b)7, lys(b)50, $\operatorname{trp}(\mathrm{b}) 51, \operatorname{gly}(\mathrm{b}) 53, \operatorname{lys}(\mathrm{a}) 97, \operatorname{asp}(\mathrm{a}) 133$} \\
\hline & & & 5-Ring & $\begin{array}{c}\mathrm{C}, \\
\text { asp96 }\end{array}$ & $\pi-\mathrm{H}$ & 4.01 & -0.7 & \\
\hline \multirow{5}{*}[\mathrm{Cu}-\mathrm{NHC1}]{$-6 \mathrm{JBR}$} & \multirow{5}{*}{-12.3} & \multirow{5}{*}{0.76} & $\mathrm{Cl}$ & $\begin{array}{c}\mathrm{O}, \\
\text { asp153 }\end{array}$ & H-donor & 3.55 & -1.7 & \multirow{5}{*}{$\begin{array}{c}\text { met390, gly389, asn391, val393, leu392, gly42, leu44, gly43, } \\
\text { arg327, tyr154, his181, trp108, thr182 }\end{array}$} \\
\hline & & & $\mathrm{Cl}$ & $\begin{array}{c}\mathrm{O} \\
\text { asp153 }\end{array}$ & H-donor & 2.83 & -0.7 & \\
\hline & & & $\mathrm{N}$ & $\begin{array}{c}\mathrm{O} \\
\text { asp338 }\end{array}$ & Ionic & 3.95 & -0.6 & \\
\hline & & & 5-Ring & $\begin{array}{c}\mathrm{N} \\
\arg 289\end{array}$ & $\pi$-cation & 4.09 & -1.4 & \\
\hline & & & 5-Ring & $\begin{array}{c}\mathrm{N}, \\
\text { lys } 294\end{array}$ & $\pi$-cation & 4.07 & -1.3 & \\
\hline \multirow{4}{*}{ [Cu-NHSi1]-6JBR } & \multirow{4}{*}{-12.6} & \multirow{4}{*}{0.74} & $\mathrm{Si}$ & $\mathrm{N}$, gly 43 & $\begin{array}{c}\text { H- } \\
\text { acceptor }\end{array}$ & 3.32 & -3.2 & \multirow{4}{*}{$\begin{array}{c}\text { gly389, leu392, asp388, met390, } \operatorname{trp} 108, \text { his } 181, \text { asn391, } \\
\text { val393, gly42, leu44, val324, } \arg 327\end{array}$} \\
\hline & & & $\mathrm{Si}$ & $\begin{array}{l}\mathrm{N} \\
\arg 289\end{array}$ & $\begin{array}{c}\text { H- } \\
\text { acceptor }\end{array}$ & 3.65 & -0.1 & \\
\hline & & & 5-Ring & $\begin{array}{c}\mathrm{N} \\
\arg 289\end{array}$ & $\pi$-cation & 4.19 & -1.4 & \\
\hline & & & 5-Ring & $\begin{array}{c}\mathrm{N} \\
\text { lys } 294\end{array}$ & $\pi$-cation & 3.92 & -1.2 & \\
\hline \multirow{3}{*}[\mathrm{Cu}-\mathrm{NHC}2]{$-6 \mathrm{JBR}$} & & & $\mathrm{Cl}$ & $\begin{array}{c}\mathrm{O} \\
\text { asp153 }\end{array}$ & H-donor & 2.69 & -0.5 & \\
\hline & -13.0 & 1.16 & 5-Ring & $\mathrm{N}$, gly 43 & $\pi-\mathrm{H}$ & 3.60 & -0.8 & val393, ser41, leu44, gly42, $\arg 327$, his181, trp108, his212, \\
\hline & & & 5-Ring & $\begin{array}{c}\mathrm{N} \\
\arg 289\end{array}$ & $\pi$-cation & 3.64 & -0.6 & met390, gly389, asp388 \\
\hline & & & 5-Ring & $\mathrm{N}$, lys 94 & $\pi$-cation & 4.13 & -6.2 & \\
\hline & & & $\mathrm{Cl}$ & $\begin{array}{c}\mathrm{N} \\
\arg 327\end{array}$ & $\begin{array}{c}\mathrm{H}- \\
\text { acceptor }\end{array}$ & 3.46 & -0.7 & \\
\hline & & & $\mathrm{Si}$ & $\mathrm{N}$, gly43 & $\begin{array}{c}\mathrm{H}- \\
\text { acceptor }\end{array}$ & 3.10 & -1.6 & \\
\hline & & & $\mathrm{Si}$ & $\begin{array}{c}\mathrm{N} \\
\arg 289\end{array}$ & $\begin{array}{c}\mathrm{H}- \\
\text { acceptor }\end{array}$ & 3.76 & -1.3 & \\
\hline [Cu-NHSi2]-6JBR & -13.4 & 1.14 & 5-Ring & N, gly 43 & $\pi-\mathrm{H}$ & 3.42 & -1.8 & $\begin{array}{l}\text { asn391, asp388, leu392, met390, ser41, val393, leu44, gly42, } \\
\text { val324, val287, asp288, asp153, his181, thr182, trp108 }\end{array}$ \\
\hline & & & 5-Ring & $\begin{array}{c}\mathrm{N} \\
\arg 289\end{array}$ & $\pi$-cation & 4.15 & -2.2 & \\
\hline & & & 5-Ring & $\begin{array}{c}\mathrm{N} \\
\arg 289\end{array}$ & $\pi$-cation & 4.48 & -0.7 & \\
\hline & & & 5-Ring & $\begin{array}{c}\mathrm{N}, \\
\text { lys } 294\end{array}$ & $\pi$-cation & 3.78 & -8.5 & \\
\hline
\end{tabular}




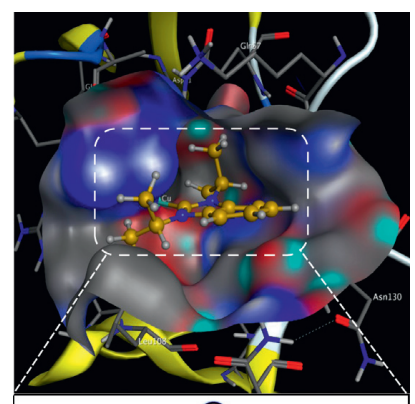

(3)

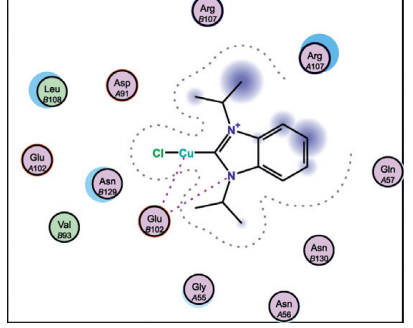

[Cu-NHC1]-4G9M

(a)
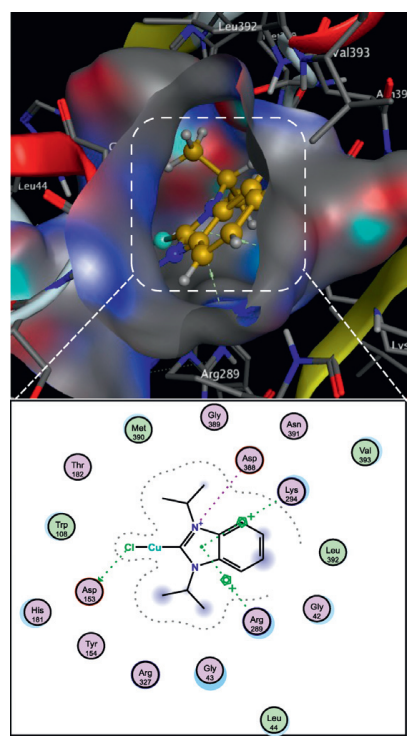

[Cu-NHC1]-6JBR

(e)
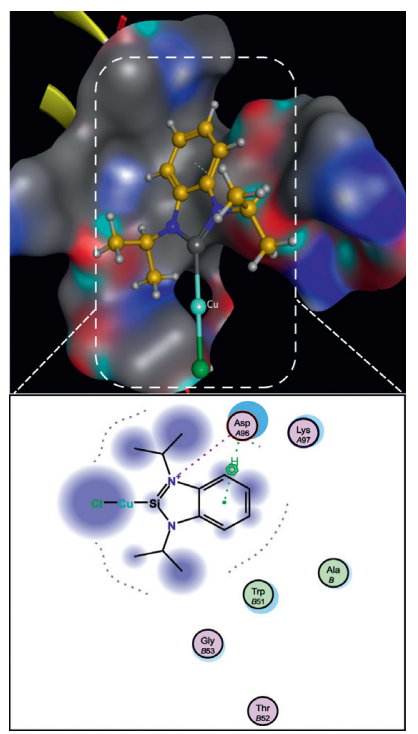

[Cu-NHSi1]-4G9M

(b)

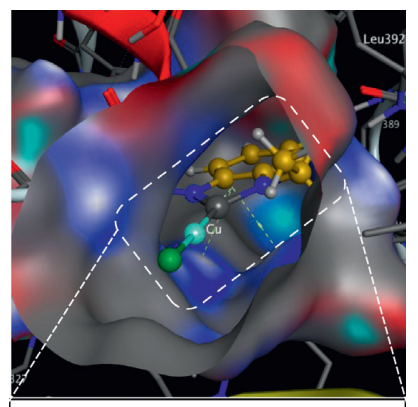

(일

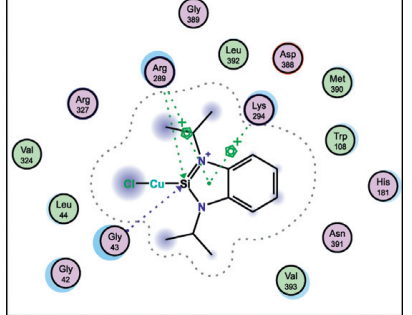

[Cu-NHSi1]-6JBR

(f)
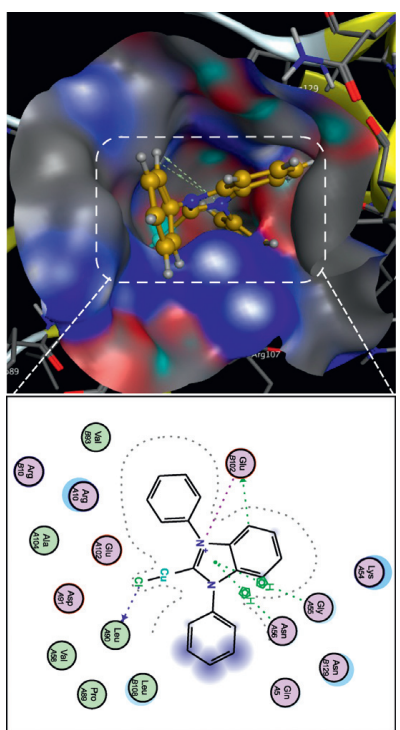

[Cu-NHC2]-4G9M

(c)

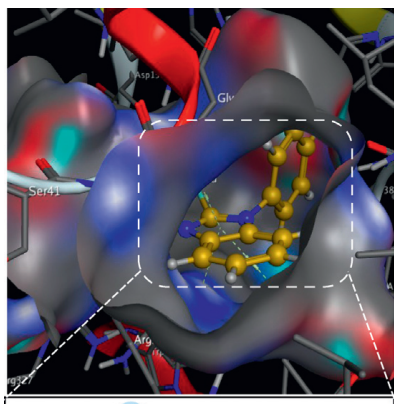

(⿶ㅛ

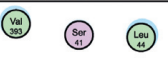

(iix)<smiles>[O][C@H]1CC[C@H](O)C1</smiles>

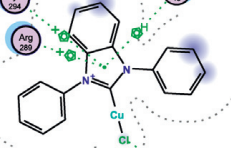

(Mat)

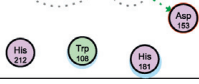

[Cu-NHC2]-6JBR

(g)
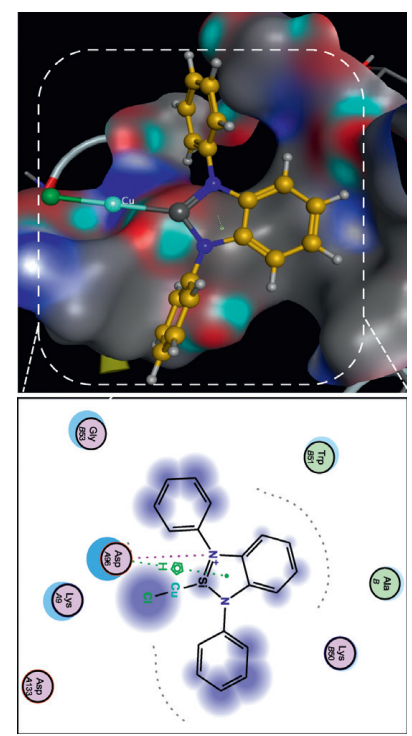

[Cu-NHSi2]-4G9M

(d)
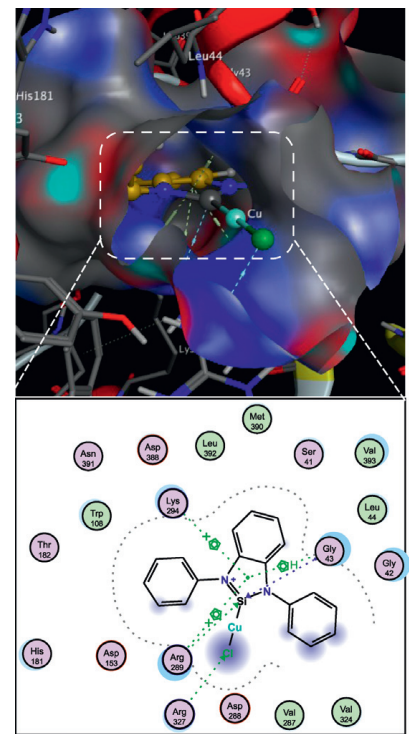

[Cu-NHSi2]-6JBR

(h)

Figure 8: Visual presentation and in-pose interaction map of ligand-4G9M and ligand-6JBR: (a) [Cu-NHC1]-4G9M, (b) [Cu-NHSi1]4G9M, (c) [Cu-NHC2]-4G9M, (d) [Cu-NHSi2]-4G9M, (e) [Cu-NHC1]-6JBR, (f) [Cu-NHSi1]-6JBR, (g) [Cu-NHC2]-6JBR, and (h) [CuNHSi2]-6JBR.

considered highly predominant given the comparison to another duo-system tricyclazole-6JBR (DS value $-10.7 \mathrm{kcal} \cdot \mathrm{mol}^{-1}$; RSMD $1.77 \AA$ ) [51], in which tricyclazole is well-known as a commercial drug for blast disease on rice plants.

The simulated inhibitions are visually illustrated in Figure 8. Intermolecular interactions detected in each site are projected on a $2 \mathrm{D}$ diagram for each inhibitory complex, while observation on 3D models infers to the spatial capacity of alternative inhibitions. Although the sites are not spacious for macromolecular or simultaneous inhibitions, all the copper tetrylenes, in particular, seem geometrically fit in the structural topography of their inhibiting sites given their continuous proximity contours. This indicates high degree of complementarity.

3.3. Molecular Docking on Average Evaluation. In an attempt to reach a brief view on the applicability of the copper tetrylenes as multipurpose drugs for both rice sheath blight caused by fungi Rhizoctonia solani and rice blast caused by fungi Magnaporthe oryzae, their molecular docking parameters regarding both proteins $4 \mathrm{G} 9 \mathrm{M}$ and $6 \mathrm{JBR}$ are summarised. The data are shown in Table 6 . Their DS values 
TABLE 6: Molecular docking parameters including the average docking score energy values, polarisability, and total hydrogen bonds of ligand-protein systems regarding both proteins 4G9M and 6JBR.

\begin{tabular}{lccc}
\hline Complex & DS $_{\text {average }}$ & Polarisability & Hydrogen bond \\
\hline Cu-NHC1 & -11.9 & 32.1 & 7 \\
Cu-NHSi1 & -12.2 & 33.6 & 6 \\
Cu-NHC2 & -12.9 & 35.9 & 9 \\
Cu-NHSi2 & 12.8 & 36.2 & 9 \\
\hline
\end{tabular}

$\mathrm{DS}_{\text {average: }}$ average docking score energy $\left(\mathrm{kcal} \cdot \mathrm{mol}^{-1}\right)$. Polarizability $\left(\AA^{3}\right) 4$.

are $-11.9,-12.2,12.9$, and $12.8 \mathrm{kcal} \cdot \mathrm{mol}^{-1}$ in respect to $\mathrm{Cu}-$ $\mathrm{NHC1}, \mathrm{Cu}-\mathrm{NHSi1}, \mathrm{Cu}-\mathrm{NHC} 2$, and Cu-NHSi2. These indicate that all the compounds are considered to exhibit strong inhibitory effects on protein structures in general. The justification is based on their relative significance in comparison to DS values representing for inhibitory capability of other duo-systems previously reported in the literature [52-54]. In addition, the polarisability of the compounds registers over $32 \AA^{3}$, indicating high polarisation. The property is of significance because it is highly conducive to protein inhibition as the polypeptide molecule is made of polarised amino acids. Therefore, all the concerned tetrylene complexes are likely compatible with applications in a biological medium, that of rice plants for specification.

\section{Conclusion}

This study proposes a family of copper tetrylenes $(\mathrm{Cu}-\mathrm{NHC1}$, $\mathrm{Cu}-\mathrm{NHC2}$, Cu-NHSi1, and $\mathrm{Cu}-\mathrm{NHSi} 2$ ) as promising inhibitors against proteins $4 \mathrm{G} 9 \mathrm{M}$ and 6JBR. DFT analysis expects the stability of the investigated compounds, thus their existability and synthesisability. Also, their molecular electronic configurations are justified conducive to intermolecular interactability. Molecular docking simulation predicts their highly stable ligand-protein inhibitory structure. Regarding protein $4 \mathrm{G} 9 \mathrm{M}$, their stability is estimated in the order [Cu-NHC2]-4G9M > [Cu-NHSi1]-4G9M $\approx[\mathrm{Cu}-\mathrm{NHSi2}]-4 \mathrm{G}$ $9 \mathrm{M}>[\mathrm{Cu}-\mathrm{NHC1}]-4 \mathrm{G} 9 \mathrm{M}$. In contrast, the corresponding order for ligand-6JBR systems is [Cu-NHSi2]-6JBR > [Cu-NHC2]$6 \mathrm{JBR} \approx[\mathrm{Cu}-\mathrm{NHSi1}]-6 \mathrm{JBR}>[\mathrm{Cu}-\mathrm{NHC1}]-6 \mathrm{JBR}$. The significance of their polarisability is also conducive to their applicability as drugs used in biological mediums. The results encourage further investigation and development on copper tetrylenes, especially towards treatments for rice sheath blight, rooted from the infection of fungi Rhizoctonia solani and rice blast, caused by fungi Magnaporthe oryzae.

\section{Data Availability}

The data of $R$. solani enzyme crystal structure can be referenced at Worldwide Protein Data Bank database under entry PDB-4G9M (DOI: 10.2210/pdb4G9M/pdb). The data of $M$. oryzae enzyme crystal structure can be referenced at the Worldwide Protein Data Bank database under entry PDB-6JBR (DOI: 10.1042/BCJ20190289).

\section{Conflicts of Interest}

The authors declare no conflicts of interest.

\section{Acknowledgments}

This research was funded by the Ministry of Education and Training for the Development of Science and Technology, with CODE of B2021-DHH-13. The authors acknowledge partial support of Hue University under the Core Research Program, Grant no. NCM.DHH.2020.04.

\section{Supplementary Materials}

Cartesian coordinates of the DFT-optimised copper tetrylene structures are included in the supporting information file. (Supplementary Materials)

\section{References}

[1] D. C. Pham, T. H. Nguyen, U. T. P. Ngoc, N. T. T. Le, T. V. Tran, and D. H. Nguyen, "Preparation, characterization and antifungal properties of chitosan-silver nanoparticles synergize fungicide against pyricularia oryzae," Journal of Nanoscience and Nanotechnology, vol. 18, no. 8, pp. 52995305, 2018.

[2] S. H. Ou, Rice Diseases, IRRI, Varanasi, India, 1985.

[3] S. Sreenivasaprasad, R. Johnson, S. Banniza, and M. Holderness, "Rice sheath blight - pathogen biology and diversity," in Major Fungal Diseases of Rice., pp. 201-211, Springer Science \& Business Media, Heidelberg,Germany, 2001.

[4] K. Richa, I. M. Tiwari, M. Kumari et al., "Functional characterization of novel chitinase genes present in the sheath blight resistance QTL: qsbr11-1 in rice line Tetep," Frontiers of Plant Science, vol. 7, pp. 244-310, 2016.

[5] V. T. Skamnaki, W. J. Peumans, A. L. Kantsadi et al., "Structural analysis of theRhizoctonia solaniagglutinin reveals a domain-swapping dimeric assembly," FEBS Journal, vol. 280, no. 8, pp. 1750-1763, 2013.

[6] M. Hahn, "The rising threat of fungicide resistance in plant pathogenic fungi: botrytis as a case study," Journal of Chemical Biology, vol. 7, no. 4, pp. 133-141, 2014.

[7] S. Wang, Y. Zhao, L. Yi et al., "Crystal structures of Magnaporthe oryzae trehalose-6-phosphate synthase (MoTps1) suggest a model for catalytic process of Tps1," Biochemical Journal, vol. 476, no. 21, pp. 3227-3240, 2019.

[8] A. J. Arduengo, R. L. Harlow, and M. Kline, "A stable crystalline carbene," Journal of the American Chemical Society, vol. 113, no. 1, pp. 361-363, 1991.

[9] A. J. Arduengo, "Looking for stable carbenes: the difficulty in starting anew," Accounts of Chemical Research, vol. 32, no. 11, pp. 913-921, 1999.

[10] A. J. Arduengo, H. V. R. Dias, J. C. Calabrese, and F. Davidson, "Homoleptic carbene-silver(I) and carbenecopper(I) complexes," Organometallics, vol. 12, no. 9, pp. 3405-3409, 1993. 
[11] B. A. Shainyan, A. V. Kuzmin, and M. Y. Moskalik, "Carbenes and nitrenes. An overview," Computational and Theoretical Chemistry, vol. 1006, pp. 52-61, 2013.

[12] S. Ajori, S. Haghighi, and R. Ansari, "Tensile characteristics of carbene-functionalized CNTs subjected to physisorption of polymer chains: a molecular dynamics study," Journal of Molecular Modeling, vol. 25, p. 318, 2019.

[13] A. Kascatan-Nebioglu, M. J. Panzner, C. A. Tessier, C. L. Cannon, and W. J. Youngs, "N-Heterocyclic carbenesilver complexes: a new class of antibiotics," Coordination Chemistry Reviews, vol. 251, no. 5-6, pp. 884-895, 2007.

[14] S. Roland, C. Jolivalt, T. Cresteil et al., "Investigation of a series of silver-N-Heterocyclic carbenes as antibacterial agents: activity, synergistic effects, and cytotoxicity," Chemistry - A European Journal, vol. 17, no. 5, pp. 1442-1446, 2011.

[15] W. Streciwilk, J. Cassidy, F. Hackenberg, H. Müller-Bunz, F. Paradisi, and M. Tacke, "Synthesis, cytotoxic and antibacterial studies of p-benzyl-substituted NHC-silver(I) acetate compounds derived from 4,5-di-p-diisopropylphenyl- or 4,5-di-p-chlorophenyl-1H-imidazole," Journal of Organometallic Chemistry, vol. 749, pp. 88-99, 2014.

[16] C. N. Banti and S. K. Hadjikakou, "Anti-proliferative and antitumor activity of silver(i) compounds," Metallomics, vol. 5, no. 6, pp. 569-596, 2013.

[17] L. Eloy, A.-S. Jarrousse, M.-L. Teyssot et al., “Anticancer activity of silver-N-heterocyclic carbene complexes: caspaseindependent induction of apoptosis via mitochondrial apoptosis-inducing factor (AIF)," ChemMedChem, vol. 7, no. 5, pp. 805-814, 2012.

[18] S. Ray, R. Mohan, J. K. Singh et al., "Anticancer and antimicrobial metallopharmaceutical agents based on palladium, gold, and silver N-heterocyclic carbene complexes," Journal of the American Chemical Society, vol. 129, no. 48, pp. 1504215053, 2007.

[19] T. Q. Bui, H. T. Phuong Loan, T. T. Ai My et al., "A density functional theory study on silver and bis-silver complexes with lighter tetrylene: are silver and bis-silver carbenes candidates for SARS-CoV-2 inhibition? Insight from molecular docking simulation," RSC Advances, vol. 10, no. 51, pp. 30961-30974, 2020.

[20] D. T. Cohen and K. A. Scheidt, "Cooperative Lewis acid/Nheterocyclic carbene catalysis," Chemical Science, vol. 3, no. 1, pp. 53-57, 2012.

[21] T. A. K. Al-Allaf, M. T. Ayoub, and L. J. Rashan, "Synthesis and characterization of novel biologically active platinum(II) and palladium(II) complexes of some $\beta$-carboline alkaloids," Journal of Inorganic Biochemistry, vol. 38, no. 1, pp. 47-56, 1990.

[22] M. Vincent, P. Hartemann, and M. Engels-Deutsch, "Antimicrobial applications of copper," International Journal of Hygiene and Environmental Health, vol. 219, no. 7, pp. 585591, 2016.

[23] G. Ren, D. Hu, E. W. C. Cheng, M. A. Vargas-Reus, P. Reip, and R. P. Allaker, "Characterisation of copper oxide nanoparticles for antimicrobial applications," International Journal of Antimicrobial Agents, vol. 33, no. 6, pp. 587-590, 2009.

[24] G. Grass, C. Rensing, and M. Solioz, "Metallic copper as an antimicrobial surface," Applied and Environmental Microbiology, vol. 77, no. 5, pp. 1541-1547, 2011.

[25] J. P. Ruparelia, A. K. Chatterjee, S. P. Duttagupta, and S. Mukherji, "Strain specificity in antimicrobial activity of silver and copper nanoparticles," Acta Biomaterialia, vol. 4, no. 3, pp. 707-716, 2008.

[26] C. N. Hancock, L. H. Stockwin, B. Han et al., "A copper chelate of thiosemicarbazone NSC 689534 induces oxidative/
ER stress and inhibits tumor growth in vitro and in vivo," Free Radical Biology and Medicine, vol. 50, no. 1, pp. 110-121, 2011.

[27] M. M. Zangeneh, H. Ghaneialvar, M. Akbaribazm et al., "Novel synthesis of Falcaria vulgaris leaf extract conjugated copper nanoparticles with potent cytotoxicity, antioxidant, antifungal, antibacterial, and cutaneous wound healing activities under in vitro and in vivo condition," Journal of Photochemistry and Photobiology B: Biology, vol. 197, Article ID 111556, 2019.

[28] I. M. Kapetanovic, "Computer-aided drug discovery and development (CADDD): in silico-chemico-biological approach," Chemico-Biological Interactions, vol. 171, no. 2, pp. 165-176, 2008

[29] L. G. Ferreira, R. N. Dos Santos, G. Oliva, and A. D. Andricopulo, "Molecular Docking and Structure-Based Drug Design Strategies," Molecule, vol. 20, no. 7, pp. 13384-13421, 2015.

[30] Y. Kaddouri, B. Bouchal, F. Abrigach, M. Elkodadi, and M. Bellaoui, "Predictions, and antimicrobial evaluation of novel mono- and tetra-alkylated pyrazole and triazole ligands," Journal of Chemistry, vol. 2021, Article ID 6663245, 11 pages, 2021.

[31] A. R. Bhat, R. S. Dongre, F. A. Almalki et al., "Synthesis, biological activity and POM/DFT/docking analyses of annulated pyrano [2,3-d] pyrimidine derivatives: identification of antibacterial and antitumor pharmacophore sites," Bioorganic Chemistry, vol. 106, Article ID 104480, 2021.

[32] Y. Kaddouri, F. Abrigach, E. B. Yousfi et al., "New heterocyclic compounds: synthesis, antioxidant activity and computational insights of nano-antioxidant as ascorbate peroxidase inhibitor by various cyclodextrins as drug delivery systems," Current Drug Delivery, vol. 18, no. 3, pp. 334-349, 2021.

[33] Y. Kaddouri, F. Abrigach, S. Ouahhoud et al., "Synthesis, characterization, reaction mechanism prediction and biological study of mono, bis and tetrakis pyrazole derivatives against Fusarium oxysporum f. sp. Albedinis with conceptual DFT and ligand-protein docking studies," Bioorganic Chemistry, vol. 110, Article ID 104696, 2021.

[34] D. J. F. ] M. J. Frisch, G. W. Trucks, H. B. Schlegel et al., Gaussian 09, Gaussian Inc., CT, USA, 2009.

[35] L. S. Kassel, "Density-functional exchange-energy approximation with correct asymptotic behavior," Physical Review A, vol. 38, pp. 3098-3100, 1988.

[36] A. Schäfer, H. Horn, and R. Ahlrichs, "Fully optimized contracted Gaussian basis sets for atoms Li to Kr," The Journal of Chemical Physics, vol. 97, no. 4, pp. 2571-2577, 1992.

[37] F. Weigend and R. Ahlrichs, "Balanced basis sets of split valence, triple zeta valence and quadruple zeta valence quality for $\mathrm{H}$ to Rn: design and assessment of accuracy," Physical Chemistry Chemical Physics, vol. 7, no. 18, pp. 3297-3305, 2005.

[38] A. E. Reed, R. B. Weinstock, and F. Weinhold, "Natural population analysis," The Journal of Chemical Physics, vol. 83, no. 2, pp. 735-746, 1985.

[39] T. Koopmans, "Über die Zuordnung von Wellenfunktionen und Eigenwerten zu den Einzelnen Elektronen Eines Atoms," Physica, vol. 1, no. 1-6, pp. 104-113, 1934.

[40] I. Lukovits, E. Kálmán, and F. Zucchi, "Corrosion inhibitorscorrelation between electronic structure and efficiency," Corrosion, vol. 57, no. 1, pp. 3-8, 2001.

[41] A. J. Sadlej, "Medium-size polarized basis sets for high-level correlated calculations of molecular electric properties," Collection of Czechoslovak Chemical Communications, vol. 53, no. 9, pp. 1995-2016, 1988. 
[42] K. Hohn and L. J. Sham, "Self-consistent equations including exchange and correlation effects," Physical Review, vol. 140, pp. 1133-1138, 1965.

[43] O. Tarasova, V. Poroikov, and A. Veselovsky, "Molecular docking studies of HIV-1 resistance to reverse transcriptase inhibitors: mini-review," Molecules, vol. 23, pp. 11-13, 2018.

[44] K.-M. Thai, D.-P. Le, N.-V.-K. Tran, T.-T.-H. Nguyen, T.-D. Tran, and M.-T. Le, "Computational assay of Zanamivir binding affinity with original and mutant influenza neuraminidase 9 using molecular docking," Journal of Theoretical Biology, vol. 385, pp. 31-39, 2015.

[45] T.-D. Ngo, T.-D. Tran, M.-T. Le, and K.-M. Thai, "Computational predictive models for P-glycoprotein inhibition of inhouse chalcone derivatives and drug-bank compounds," Molecular Diversity, vol. 20, no. 4, pp. 945-961, 2016.

[46] B. V Suresh, Solid State Devices and Technology, Pearson Education India, Chennai, India, 2010.

[47] B. Rosenberg, "Electrical conductivity of proteins," Nature, vol. 193, no. 4813, pp. 364-365, 1962.

[48] V. N. Kharkyanen, E. G. Petrov, and I. I. Ukrainskii, "DonorAcceptor model of electron transfer through proteins," Journal of Theoretical Biology, vol. 73, no. 1, pp. 29-50, 1978.

[49] M. Cordes and B. Giese, "Electron transfer in peptides and proteins," Chemical Society Reviews, vol. 38, no. 4, pp. 892-901, 2009.

[50] Y. Ding, Y. Fang, J. Moreno, J. Ramanujam, M. Jarrell, and M. Brylinski, "Assessing the similarity of ligand binding conformations with the Contact Mode Score," Computational Biology and Chemistry, vol. 64, pp. 403-413, 2016.

[51] B. T. P. Thuy, T. T. A. My, N. T. T. Hai et al., "A molecular docking simulation study on potent inhibitors against $R h i$ zoctonia solani and Magnaporthe oryzae in rice: silvertetrylene and bis-silver-tetrylene complexes vs. validamycin and tricyclazole pesticides," Structural Chemistry, vol. 32, pp. 135-148, 2020.

[52] R. S. Cheke, “The molecular docking study of potential drug candidates showing anti-COVID-19 activity by exploring of therapeutic targets of SARS-CoV-2," Eurasian Journal of Medicine and Oncology.vol. 4, pp. 185-195, 2020.

[53] T. Vu, D. Vu, P. Nguyen, and D. Tran, "Virtual screening, oriented-synthesis and evaluation of lipase inhibitory activity of benzyl amino chalcone derivatives," MedPharmRes, vol. 1, no. 1, pp. 26-36, 2017.

[54] R. Yu, L. Chen, R. Lan, R. Shen, and P. Li, "Computational screening of antagonists against the SARS-CoV-2 (COVID19) coronavirus by molecular docking," International Journal of Antimicrobial Agents, vol. 56, no. 2, Article ID 106012, 2020. 